\title{
DECLARATIONS OF THE COUNCIL OF LITHUANIA 1917-1918
}

\author{
DECLARATION 11 DECEMBER 1917
}

I

The Council of Lithuania, the sole representative of the Lithuanian nation as acknowledged by Lithuanians at home and abroad, on the basis of the recognized right of self-determination of nations and of the decision of the Lithuanian Conference in Vilnius on 18-23 September 1917 , hereby proclaims the restoration of an independent democratically organized Lithuanian State, with Vilnius as its capital, and the abolition of all political ties which have ever existed with other nations.

II

The Council of Lithuania applies to the German Empire for protection and aid in organizing this State and protecting its interests in the peace negotiations. Taking into account the vital interests of Lithuania, which requires without delay close enduring ties with the German Empire, the Council of Lithuania favours a firm eternal union of the Lithuanian State with the German Empire; that union should be formed on the basis of military and communications conventions, common customs and monetary systems.

Read Endorsed Signed by

Kaunas, December 10, 1917

A. Smetona, Chairman of the Council of Lithuania

S. Kairys, Deputy Chairman of the Council of Lithuania

Vladislovas Mironas, Deputy Chairman of the Council of Lithuania

Dr. J. Šaulys, Secretary General of the Council of Lithuania

P. Klimas, Second Secretary of the Council of Lithuania

Justinas Staugaitis, Member of the Council of Lithuania

Freiherr von Lersner, Representative of the Imperial Chancellor and Ministry of Foreign Affairs

[15 members endorsed the Declaration, 1 abstained and 3 opposed.]

11 December 1917

Translated from the Lithuanian, see: Lietuvos Valstybès Tarybos protokolai 1917-1918, ed. A. Eidintas, R. Lopata (Vilnius, 1991), pp. 155-157. 


\section{DECLARATION OF INDEPENDENCE}

The Council of Lithuania in its session of 16 February 1918 decided unanimously to address the governments of Russia, Germany and other states with the following declaration:

The Council of Lithuania, as the sole representative of the Lithuanian nation, on the basis of the recognized right of self-determination of nations and of the decision of the Lithuanian Conference in Vilnius, on 18-23 September 1917 hereby proclaims the restoration of an independent, democratically organized Lithuanian State, with Vilnius as capital, and the abolition of all political ties which have existed here before with other nations.

The Council of Lithuania also declares that the foundation of the Lithuanian State and its relations with other states must be determined finally by a Constituent Assembly to be convoked as soon as possible and elected by all the inhabitants of Lithuania.

Unanimously endorsed by the Members of the Lithuanian Council (Dr. J. Basanavičius, K. Bizauskas, M. Biržiška, S. Banaitis, P. Dovydaitis, St. Kairys, P. Klimas, D. Malinauskas, V. Mironas, St. Narutavičius, A. Petrulis, Dr. J. Šaulys, K. Šaulys, J. Šernas, A. Stulginskis, A. Smetona, J. Smilgevičius, J. Staugaitis, J. Vailokaitis, J. Vileišis)

Vilnius, 16 February 1918

Translated from the Lithuanian, see: Lietuvos Valstybes Tarybos protokolai 1917-1918, ed. A. Eidintas, R. Lopata (Vilnius, 1991), p. 208. 